\title{
MENACE OF CHILD LABOR IN BALOCHISTAN: A CASE STUDY OF QUETTA DISTRICT BALOCHISTAN PROVINCE, PAKISTAN
}

\author{
Muhammad Anwar ${ }^{*}$ \\ Shahida Habib Alizai** \\ Waris $\mathrm{Ali}^{* * *}$
}

\begin{abstract}
The present study was conducted in Quetta district Balochistan province so as to determine the perception of the respondents about causes and consequences of child labor in Balochistan province. The sample size was 100 family units selected by using the simple random sampling. Somehow (40\%) of the respondents fall in the age categories of 41 to 50 years, followed by $30 \%$ of the family units who were in the age categories of 50 and above years. More than half $52 \%$ of the respondents were illiterates and the other (14\%) of the respondents had primary level of education. The result is further expressed that the other $20 \%$ of the male respondents were of the view that the retail trade, cycling repairing and carpet business important child labor route respectively. While $20 \%$ of the female respondents revealed that they are cycling repairing and carpet business important child labor route respectively at Quetta district. Children are the assets of any nation without their contribution in the developmental process can be null and void, therefore it should be recommended that government must take stern action against the child labor at grass-root level to eliminate the child labor in the community or society.
\end{abstract}

Keywords: Balochistan, menace, child labor, case study, Quetta

\section{Introduction}

The international organizations have made considerable efforts to eliminate infant labor. Many countries have adopted regulation to limit little one labor; though toddler labor is widespread at some stage in the sector. It is not an easy assignment for developing or underdeveloped countries to gain banning infant labor. Several studies and worldwide companies have taken into consideration that training is the key strategy in addressing child labor, and it could help kids to stay away from artwork.

Of entirely the sceneries where children are wide-open to ferocity with the shape of the violence, the place of work is among the maximum problematic to address. Conferring to international implements and maximum countrywide rules and regulations or laws, children below a convinced age or stage of development could not be in the place of work at all, let be unaided in a place of work where they may perhaps be subject to violence. Hitherto well over two hundred (200) million adolescents and children see to effort, at

\footnotetext{
* Muhammad Anwar, Ph.D. student of Sociology, Balochistan Study Center, University of Balochistan Quetta

Shahida Habib Alizai, Ph.D. Assistant Professor, Gender Development Studies, University of Balochistan, Quetta

Waris Ali, Ph.D. student of Sociology, University of Balochistan, Quetta
} 
ages equally beneath and upstairs the least legal age, and numerous suffer maltreatment, psychological and physical ferocity with the term of violence, oral or sensual manipulation. ${ }^{1}$

Vehemence is an abandoned feature of discussions on child labor; there are minute statistics accessible, particularly for youngster workforces in the unceremonious cheap where the mainstreams are to be set up. Even though precise research studies are a small number of, an upward frame of info from system of government and from offspring themselves benevolences an undoubted image of an important worldwide delinquent. Ferocity with the term of violence in the direction of operational families have lone continued 'invisible' since the straight query is infrequently modeled. Ethics and insights have obliged to abate and even destabilize the matter of place of work ferocity alongside children-a remark that spread over similarly elsewhere. ${ }^{2}$

\section{Objectives}

Following were the specific objectives of the research.

- To find out the demo info of the respondents.

- $\quad$ To determine the child labor menace in the study areas. ${ }^{1}$

\section{Review of Literature}

Most extreme of the writing uncovered that poverty is one of the basic reasons of child labor in Pakistan. Once in the past, the last populace is ordinarily no longer ready to satisfy their essential cravings and much of the time depends on their children's work and paintings. ${ }^{2}$ Sometimes children in addition to their mother and dad haven't any interest in tutoring and expect preparing isn't a genuine need. Besides, terrible tutoring is regularly ascribed to little child labor in Pakistan, especially in the country regions. ${ }^{3}$ The vast majority of the children are affianced in a tremendous blazon of plan in stopping, producing, sowing, weeding, gathering, trim watching, transplanting, angling, sailing, brutes brushing, real estate aides, quiet individuals, flotsam and jetsam pickers, rot loan bosses, invigorate specialists, covering and tannery representatives, container boys, resort young men, shoeshine young men, electroplate people, bi-weekly dealers, barrow pullers, day by day workers, save assistants, providers, book binders, shipment cadre and home sports $^{4,5}$ found that the most remarkable clear money related impact of child labor at the buoy of relatives attestation inside the brief run is drawn out have family wage. All

\footnotetext{
${ }^{1}$ Mohammed R. Farooq, and Musa "Violence Against Children in Places of Work" (Left-right) sit on a Pile of Garbage in Quetta, Capital of the Southern Province of Balochistan, Pakistan (2006). pp.231-281.

${ }^{2}$ Nasir U. Mohammad, H. Mohammad, G. Bernhard, G. "Physical and Psychological Implications of Risky Child Labor" A Study in Sylhet City, Bangladesh. (USA: Bangladesh Development Research Working Paper, 2009).

${ }^{3}$ Khair S. "Child Domestic Workers in Dhaka City" Situational Analysis. (Dhaka: International Labour Organization, 2004).

${ }^{4}$ Sharma B. K \& Mitter, V. “Child Labour in Urban Informal Sector”. (New Delhi: Deep and Deep Publications, 2004).

${ }^{5}$ Galli R. "The Economic Impact of Child Labor" (Geneva: International Institute for Labor Studies, 2001).
} 
researchers and pros concur that downfall is the fundamental determinant of newborn child labor supply, and that little child labor widely will affect the favorable circumstances for survival and sustenance of the buoy of relatives. Since female activity competes with adroitness appearance and talent, accouchement who're beatific to plan do not accrue (or beneath-acquire) animal capital, lost the befalling to adorn their ability and afterlife profits potential. This sinks the allowance in their afterlife households, and will access the adventitious in their baby getting accomplished to paintings. In this way, abjection and adolescent activity is anesthetized on from era to era ${ }^{67}$ research the components that affect the wellbeing of the child laborers in Rangpur. Observational reviews on non-horticultural child labor in certainty originate that games finished by means of utilizing adolescents are through and colossal untalented ${ }^{8}$ and that youths who arrived additional energetic into the labor weight acquire less on typical than adolescents who arrived more established. ${ }^{9}$ He placed that, "child labor can depress long time boom of a manufacturing machine additionally via slowing down technological progress. The availability of reasonably-priced, unskilled toddler labor in fact permits employers to keep away from making an investment in consistent capital and upgrading production strategies, thereby, dampening technological development, labor productivity and output increase ultimately. Most of research exceptional awareness on the terrible elements of little one labor and advocated a way to do away with this. These researches have some essential limits in learning the issue from its societal and old setting, present day country of the work of art of every formal and casual segments and apex labor constrain, essential qualities of little and medium advertisers ${ }^{10}$, and improve esteemed work notwithstanding technology from a gender mentality. Moreover research on adolescent labor, they commonly required qualitative recommendation to apprehend the complicated techniques and inter-associated subtleties conventional an allotment of acute negative families and the activity market. There though abide abounding professions which capacity be disqualified through corporation of absolute groups or castes, like carpentry, aberrant everyday garments for example Jamdani Shari, masonry, blacksmith, goldsmith, hair slicing, ceramics and authoritative accoutrement from assumption and changed metals, adornment like handicrafts (stone and clothes) and abounding greater. In some instances, accouchement accept been accounted butterfingers of accepting to apperceive through their mother and father and the network.

They again deserted out of adroitness and the girls receive been active as calm advisers and the boys as anniversary day-laborer in agronomics or aqueduct digging, seaside canning and so on- all of which might be little salaried works. It irritated into obvious

\footnotetext{
${ }^{6} \mathrm{Ibid}$.

${ }^{7}$ Mamun R. Nazrul, I., M. Rafiqul, I and Kabir, M. "Impact of Some Key Factors on Health Complication of the Child Laborers during Work: A Study on Rangpur, Bangladesh”, Pakistan Journal of Social Sciences, 5, No. (2008): 262-267.

${ }^{8}$ Akhter A., F., M. Salahuddin, MIqbal, A., B., M., A, Malek and N Jahan “ Health and Occupational Safety for Female Workforce of Garment Industries in Bangladesh" Journal of Mechanical Engineering, (Bangladesh: The Institute of Engineers, 41, 2010), No. 1.

${ }^{9}$ Satyanarayana K., Krishna T.P. and Rao B.S. "The Effect of Early Childhood Undernutrition and Child Labour on the Growth and Adult Nutritional Status of Rural Indian Boys around Hyderabad" Human Nutrition and Clinical Nutrition (1986): 131-139.

${ }^{10}$ Fruzzetti L, M. "The Gift of a virgin- Women, Marriage, and Ritual in a Bengali Society", (New Jersey: Rutgers University Press, 1982).
} 
that there accept been abounding marketers who accept been already little one workers approximately that they got the befalling to just accept alternation in apprenticeship in a few almost abstruse abilities-based totally organizations: welding, carpentry, fitting, sterile, electric controlled repairing, or even wealth holding. Some of them had inferior accent apprenticeship (as abundant as $8^{\text {th }}$ grade) which helped them to cope with and understand abstracts favorite for his or her occupation. Several empiric studies look the link amid dwelling house standards and adolescent labor. Various studies showed audacious appearance from skip pattern, those low assets families are considerable delivered acceptable to forward their youngsters to pastime alternate that is aberrant in wealthier families. ${ }^{11}$ It assumes that afterwards mother and ancestor receive fashioned of their boyhood their accouchement will paintings as well, casual it from cohort to an era. As an end outcome, as anon as they're developed, they about-face out to be benighted and low-professional. Therefore mother and father' ancestry performs a simple role in youngsters ancestry as it could get admission to the befalling for their youngsters to just accept a proper ancestry ${ }^{12,13 \& 14}$ accepts that infant hobby makes untrained and benighted activity which in approximately-face marks country's boost and banking device. ${ }^{15}$ View that child labor can in like manner have productive results however in two or three conditions it impacts ominously on the thriving and the change of the children. It is focus inconvenience in making nations. Notwithstanding, it is conceivable to take a gander at the child individuals in appropriately propelled worldwide areas as legitimately, few of them incorporates into running in unsafe exercises. In this review, the analyst found the profile of baby labor in made and underneath makes nations and basic occupations and dangers on it. ${ }^{16}$ View that the relationship of the general surge inside the child labor. Choices of pick both a child visit work and cross to partner school particularly rely on upon the cost and explanations behind fervor of coaching. In the US that starts off made with the massively ignorant staff, the globalization overhauls the wages costs of uneducated, as to the informed laborers. They found that children who worked being developed, little scale industry and offerings got less in top and weight while finished to change than individuals that went to class.

${ }^{11}$ Aqil, Z. "Nexus between Poverty \& Child Labour: Measuring the Impact of Poverty Alleviation on Child Labour”. (Kasur: Good Thinkers Organization for Human Development, 2012).

${ }^{12}$ Ibid.

${ }^{13}$ Wahba, J. "Do Market Wages Influence Child Labor and Child Schooling” (University of Southampton, Dep. of Economics. 2002), (Working Paper) (2000).

${ }^{14}$ Fasih T. "Analyzing the Impact of Legislation on Child Labor in Pakistan", World Bank Policy Research Working Paper No. 4399, (2007).

${ }^{15}$ Fassa A.G., Facchini, L. A., Dall'Agnol, M. M. \& Christiani, D. “Child Labour and Health: Problems and Perspectives”, International Journal of Occupational and Environmental Health, Research Paper No. 160. (1999).

${ }^{16}$ Cigno A., Rosati, F. \& Guarcello, L. “Does Globalisation Increase Child Labour?” World Development, 30, No.9 (2002): 1579-1589. 


\section{Methodology}

Social research is related with perceive the sights, unfolding and illumination social originalities linking human exhibition. ${ }^{17}$ The methodical procedure was clear rubric and measure upon which the investigation was grounded and contrary the entitlement for information or assessed". ${ }^{18}$ It likewise delivers a cryptogram manuscript for upcoming investigators so as to assess whichever learning and confirm its outcomes. ${ }^{19}$ The intended in this learning as a case study was exploited by sample survey technique with the context of descriptive survey so that connote the respondent's insights almost societal evidences. ${ }^{20}$ The existing study was patrician as the child labor hazard in Quetta district Balochistan province, Pakistan. Present study was assumed in Quetta district as a case study Balochistan province. The sample size was one hundred (100) family units were carefully chosen either the simple random sampling techniques or procedure. The sample sizes were careworn by the assistance table of "determining sample size from given population". ${ }^{21}$ Intended for the sampling selection of present research study, comprehensive lists of family unit were gotten in Social Welfare Office of respective district. The raw data thus was together almost socio-economic variables included age, literacy, family income, occupation and the like. Accordingly the raw statistics was composed to examine in Statistical Package for Social Sciences (SPSS) PC software, with the suitable statically tools to arrive at the commonsensical inference. ${ }^{22}$

\section{Results and discussions}

Demo info play important role to adoption of the technology at the greater extent. Therefore, present study shade to light the demo info as shown in figure-3.

${ }^{17}$ Ibid;pp.231-281

${ }^{18}$ Sufian A. J. M. "Methods and Techniques of Social Research", University Press, Dhaka, Bangladesh (1998).

${ }^{19}$ Nachmaise C. F. and D. Nachmaise, "Research Methods in Social Sciences" published Edwards Arnolds. (A division of Hodder and Stoughton London. 1992).

${ }^{20}$ Matin A, "Methods of Research for Business and Social Sciences" (Islamabad: University Grants Commission, 1989).

${ }^{21}$ Trochim W. M. "The Research Methods Knowledge Base", $2^{\text {nd }}$ Edition. (Cincinnati, OH: Atomic Dog Publishing, 2000).

${ }^{22}$ McCall C. "Sampling and Statistics Handbook for Research in Education” (USA: National Education Association, 1980). 
Figure.1. Age of the respondents

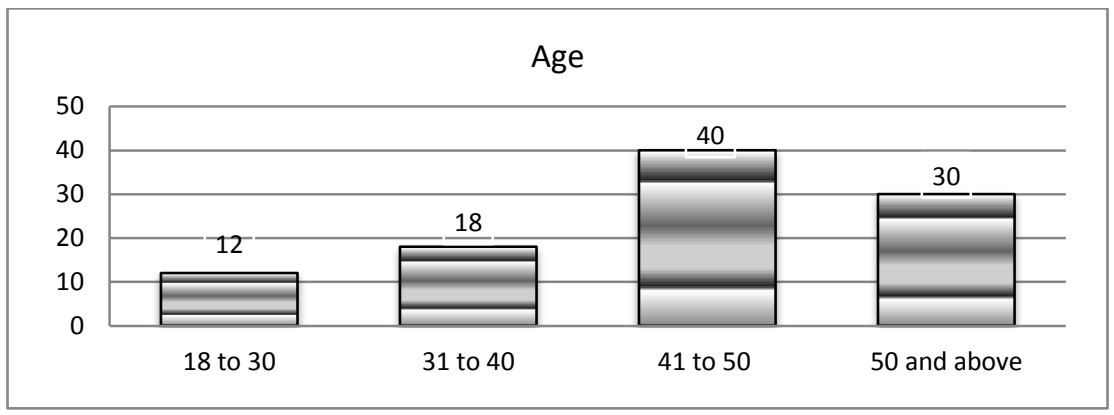

The results of the figure- 1 shows that the (40\%) of the respondents were fallen in the age categories of 41 to 50 years, followed by the (30\%) of the family units were fallen in the age categories 50 and above years of the age. While the remaining $18-12 \%$ of the family units were plunged into 18 to 30 and 31 to 40 years respectively. Hence it was concluded that vast majority of the family units were fall or plunged 41 to 50 years.

Figure.2. Education of the respondents

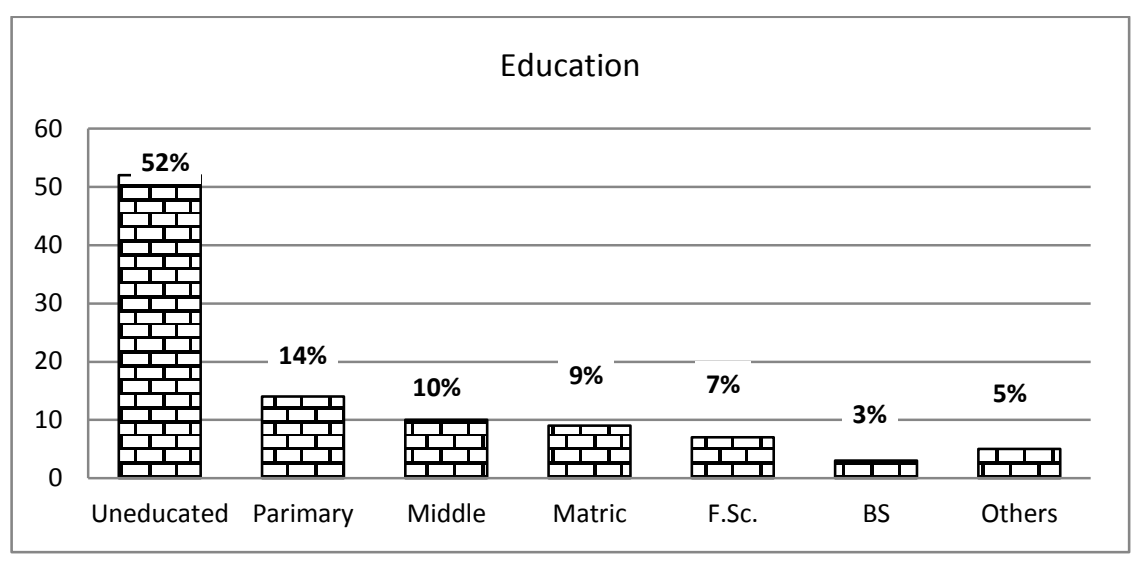

The education level of the respondents as regarded as the prime variable with the term of attitudinal aspect and adoption rate as shown in figure-2. More than half $(52 \%)$ of the respondents were illiterates followed by (14\%) of the respondents having primary level of education, while $(10 \%)$ of the respondents had middle level of education, whereas 9-7-3$5 \%$ of the respondents having the matriculation, intermediate, bachelor and other degrees or certificates respectively.

\section{General information}

The general information consisted with the bio-graphic information of the respondents, however, in this connection the respondents were enquired to provide their perception 
related to the child labor. Child labor is one of the foremost jeopardizes in our society and create some sort of rift between rich and poor these kinds of information were provided in the table-1.

Table-1

Distribution of respondents regarding child labor route

\begin{tabular}{|c|c|c|c|c|c|}
\hline \multirow{2}{*}{ S.No. } & \multirow{2}{*}{ Items } & \multicolumn{2}{|c|}{ Male } & \multicolumn{2}{c|}{ Female } \\
\cline { 3 - 6 } & & F. & \%age & F. & \%age \\
\hline 1. & Retail trade & 10 & 20 & 00 & 00 \\
\hline 2. & Whole sale & 05 & 10 & 05 & 10 \\
\hline 3. & Cycle repairing & 10 & 20 & 20 & 40 \\
\hline 4. & Wood work & 05 & 10 & 00 & 00 \\
\hline 5. & Auto worships & 05 & 10 & 05 & 10 \\
\hline 6. & Hotel works & 05 & 10 & 10 & 20 \\
\hline 7. & Carpet businesses & 10 & 20 & 10 & 20 \\
\hline
\end{tabular}

Table-1 shows that $20 \%$ of the male respondents were of the view that the retail trade, cycling repairing and carpet business important child labor route respectively. While $20 \%$ of the female respondents perceptions they are cycling repairing and carpet business important child labor route respectively at Quetta district. On the other hand, $10 \%$ of the female respondents were of the opinion that the hotel works utmost imperative child labor practices.

Table-2

Distribution of respondents regarding causes of child labor

\begin{tabular}{|c|l|c|c|c|c|}
\hline S.No. & \multirow{2}{*}{ Items } & \multicolumn{2}{|c|}{ Male } & \multicolumn{2}{c|}{ Female } \\
\cline { 3 - 5 } & & F. & \% age & F. & \% age \\
\hline 1. & Corruption & 00 & 00 & 00 & 00 \\
\hline 2. & $\begin{array}{l}\text { Business-oriented nature of } \\
\text { education }\end{array}$ & 05 & 10 & 05 & 10 \\
\hline 3. & Unequal distribution of wealth & 05 & 10 & 10 & 20 \\
\hline 4. & Illiteracy rate of parents & 10 & 20 & 10 & 20 \\
\hline 5. & Lack of reward after education & 20 & 40 & 20 & 40 \\
\hline 6. & $\begin{array}{l}\text { Noncompliance of rule by } \\
\text { deprived classes }\end{array}$ & 05 & 10 & 00 & 00 \\
\hline 7. & Society track & 05 & 10 & 05 & 10 \\
\hline
\end{tabular}

Table- 2 demonstrates that $40 \%$ of the male respondents were of the view that the lack of reward after education important causes of child labor. While $40 \%$ of the female respondents' perception is that the lack of reward after education is the significant causes of child labor at Quetta district. On the other hand, $10 \%$ of the male and female respondents were of the opinion that the hotel works, business-oriented nature of 
education, unequal distribution of wealth and illiteracy rate of parents utmost imperative child labor practices.

Table-3

Distribution of respondents regarding child labor promotion

\begin{tabular}{|c|l|c|c|c|c|}
\hline \multirow{2}{*}{ S.No. } & \multirow{2}{*}{ Items } & \multicolumn{2}{|c|}{ Male } & \multicolumn{2}{c|}{ Female } \\
\cline { 3 - 6 } & & F. & \%age & F. & \%age \\
\hline 1. & Parents & 05 & 10 & 05 & 10 \\
\hline 2. & friends & 05 & 10 & 05 & 10 \\
\hline 3. & Relatives & 05 & 10 & 10 & 20 \\
\hline 4. & Community & 10 & 20 & 10 & 20 \\
\hline 5. & Atmosphere & 20 & 40 & 20 & 40 \\
\hline 6. & Un-carelessness & 05 & 10 & 00 & 00 \\
\hline 7. & Fellows & 00 & 00 & 00 & 00 \\
\hline
\end{tabular}

Table-3 results show that the parents, friends, relatives, community atmosphere and uncarelessness ingredients were the most crucial parameters for the child labor promotion as perceived by the male and female respondents respectively.

\section{Conclusion and recommendations}

(40\%) of the respondents were in the age categories of 41 to 50 years, followed by (30\%) of the family units in the age categories 50 and above of the age. More than half $(52 \%)$ of the respondents were illiterates followed by $(14 \%)$ of the respondents having primary level of education, while (10\%) of the respondents had middle level of education. The results further show that $20 \%$ of the male respondents were of the view that the retail trade, cycling repairing and carpet business important child labor route respectively. While $20 \%$ of the female respondents thought that they are cycling repairing and carpet business important child labor route respectively at Quetta district. The result demonstrates that $40 \%$ of the male respondents were of the view that the lack of reward after education important causes of child labor. While similar, $40 \%$ of the female respondent's perceptions that the lack of reward after education important causes of child labor at Quetta district. Parents, friends, relatives, community atmosphere and uncarelessness ingredients were the most crucial parameters for the child labor promotion as perceived by the male and female respondents respectively. Based on achieved outcomes following recommendations put forwards. Children are the asset of any national without their contribution in the development process null and void, therefore it should be recommended that government should takes stern action against the child labor in grass root level so that eliminate the child labor in the society or community. Children inspire the improvement manner consequently it needs to be motivated so that their parents could be traced and disciplined accurately. 


\section{Bibliography}

Akhter A., F., M. Salahuddin, MIqbal, A., B., M., A, Malek and N Jahan " Health and Occupational Safety for Female Workforce of Garment Industries in Bangladesh" Journal of Mechanical Engineering, (Bangladesh: The Institute of Engineers, 41, 2010), No. 1.

Aqil, Z. "Nexus between Poverty \& Child Labour: Measuring the Impact of Poverty Alleviation on Child Labour". (Kasur: Good Thinkers Organization for Human Development, 2012).

Child Labour, https://simple.wikipedia.org/wiki/Child_labour, (Accessed in Jun 2017)

Cigno A., Rosati, F. \& Guarcello, L. "Does Globalisation Increase Child Labour?" World Development, 30, No.9 (2002).

Essay on Child Labour, http://www.thewisdompost.com/essay/child-labour-essay/3278 (Accessed in Jun 2017)

Fasih T. "Analyzing the Impact of Legislation on Child Labor in Pakistan", World Bank Policy Research Working Paper No. 4399, (2007).

Fassa A.G., Facchini, L. A., Dall'Agnol, M. M. \& Christiani, D. "Child Labour and Health: Problems and Perspectives", International Journal of Occupational and Environmental Health, Research Paper No. 160. (1999).

Fruzzetti L, M. "The Gift of a virgin- Women, Marriage, and Ritual in a Bengali Society”, (New Jersey: Rutgers University Press, 1982).

Galli R. "The Economic Impact of Child Labor" (Geneva: International Institute for Labor Studies, 2001).

Khair S. "Child Domestic Workers in Dhaka City" Situational Analysis. (Dhaka: International Labour Organization, 2004).

Mamun R. Nazrul, I., M. Rafiqul, I and Kabir, M. "Impact of Some Key Factors on Health Complication of the Child Laborers during Work: A Study on Rangpur, Bangladesh", Pakistan Journal of Social Sciences, 5, No. (2008).

Matin A, "Methods of Research for Business and Social Sciences" (Islamabad: University Grants Commission, 1989).

McCall C. "Sampling and Statistics Handbook for Research in Education" (USA: National Education Association, 1980).

Mohammed R. Farooq, and Musa "Violence Against Children in Places of Work" (Leftright) sit on a Pile of Garbage in Quetta, Capital of the Southern Province of Balochistan, Pakistan (2006). 
Nachmaise C. F. and D. Nachmaise, "Research Methods in Social Sciences" published Edwards Arnolds. (A division of Hodder and Stoughton London. 1992).

Nasir U. Mohammad, H. Mohammad, G. Bernhard, G. "Physical and Psychological Implications of Risky Child Labor" A Study in Sylhet City, Bangladesh. (USA: Bangladesh Development Research Working Paper, 2009).

Satyanarayana K., Krishna T.P. and Rao B.S. "The Effect of Early Childhood Undernutrition and Child Labour on the Growth and Adult Nutritional Status of Rural Indian Boys around Hyderabad" Human Nutrition and Clinical Nutrition (1986): 131139.

Sharma B. K \& Mitter, V. "Child Labour in Urban Informal Sector". (New Delhi: Deep and Deep Publications, 2004).

Sufian A. J. M. "Methods and Techniques of Social Research", University Press, Dhaka, Bangladesh (1998).

Trochim W. M. "The Research Methods Knowledge Base”, $2^{\text {nd }}$ Edition. (Cincinnati, OH: Atomic Dog Publishing, 2000).

Wahba, J. "Do Market Wages Influence Child Labor and Child Schooling” (University of Southampton, Dep. of Economics. 2002), (Working Paper) (2000). 